\title{
Analysis of Parliamentary Elections Costs in the Czech Republic
}

\author{
Martin KRÁL, Ladislav HÁJEK \\ University of Hradec Králové, Hradec Králové, Czech Republic \\ \{martin.kral.2, ladislav.hajek\}@uhk.cz
}

\begin{abstract}
In recent years, more and more countries are in the so-called crisis of democracy. One of its symptoms is the lack of interest of a growing group of citizens on public affairs, which is reflected in long-term declining voter turnout. An exception is not even the Czech Republic, which, unlike most other European Union states, has no alternative form of voting that could have the potential to hinder the growing trend of apathy in society. However, every election in the Czech Republic is relatively costly, the country spends more than CZK 1 billion a year, most of which is the cost of municipalities. The aim of the paper is to analyze the most significant costs of these municipalities, using the data of the Czech Statistical Office and the Ministry of Finance of the Czech Republic. Significant differences in individual cost items have been identified, including in municipalities that are similar in size (number of eligible voters, number of electoral districts), as well as their powers (statutory cities, municipalities with extended powers, etc.). The possible way to reduce these differences (and costs) is to reduce the number of electoral districts, leading in particular to a fall in wage costs for members of the district electoral commission, which represent the most significant part of the total cost of municipalities.
\end{abstract}

Keywords: Elections, Voter Turnout, Voting, Costs.

\section{Introduction}

Before 1989, the ruling socialist regime used the election as a mechanism to test the loyalty of the population while maintaining legitimacy for the government without giving voters the real opportunity to express their preferences in the open competition of political parties. The breakthrough occurred with 1989, from which it is possible to consider the election as the real possibility for political parties to offer their visions and programs to fulfill them, but also voters with their right to freely express their preferences. [8].

However, the initial enthusiasm of citizens for the choice of political party choice has faded after more than twenty years of free society and democracy is at the socalled crisis point. Its manifestation is the declining interest of citizens in public events, and hence the declining electoral participation in most European states. [19] In 
the Czech Republic, this influence may influence the voting method, which remains in the current dynamic period, on the difference from other democratically developed countries, virtually unchanged. Only a traditional vote is allowed, consisting simply of the voter coming to the respective polling station and the ballot to the ballot box.

According to article No. 18 of the Constitution of the Czech Republic, every citizen who has reached the age of 18 years has the right to vote. [13] Whether or not to participate in the election depends, in addition to political conviction or awareness of the importance of the electoral process, on the circumstances surrounding his or her personal life [7]. Participants in the theory of participation [1, 9, 20] agree on a total of five approaches. The first is the theory of resources, which emphasizes the socioeconomic factors and the physical ability of the citizen to sacrifice time and money to participate in the elections. The second is the so-called mobilization theory, respectively. The pressures of various social groups, along with the positive and negative mobilization potential of political parties. The third is the theory of a specific context, which can be briefly described as the influence of the importance of the individual elections in the voter's eyes, or even the charisma of the individual candidates. The other two theories deal with the sociological and psychological justification of the electoral participation, which, however, does not necessarily reflect only the objective political interests of voters, but also their influence on the social environment. [2] The objective of each country should be to set up such a mix of factors so that the turnout is as high as possible and the money spent on the elections is spent as efficiently as possible.

\section{Elections in the Czech Republic}

At present, a large number of elections are executed in the Czech Republic - elections to the Chamber of Deputies of the Parliament of the Czech Republic (Parliamentary elections), to the Senate of the Parliament of the Czech Republic (Senate), to the municipal councils, to the regional councils, to the European Parliament and presidential elections. In the last 20 years there has been a significant increase in the number of executing elections; since 1993 there have been 21 nationwide elections in the Czech Republic, and over the next ten years, 12 regular nationwide elections will execute. [21].

Such a number of many elections give citizens the opportunity to participate very much and fairly often in elections and to show their preferences at local and nationwide levels, but at the same time, a very high number of elections is very expensive, see Table 1. Since 2010, elections in the Czech Republic amounted to a total of CZK 4.25 billion. The most expensive was years 2010 and 2014 (more than CZK 1 billion); this was due to the execution of more types of elections at different dates (in 2010 elections to the Chamber of Deputies of the Parliament of the Czech Republic and elections to local self-government units took place in 2014, in 2014 also elections to regional self-government units, but also elections to the European Parliament). 
Table 1. Costs connected with elections in the Czech Republic (mil. CZK) [11].

\begin{tabular}{lrrrrrrrr}
\hline Type of elections & $\mathbf{2 0 1 0}$ & $\mathbf{2 0 1 1}$ & $\mathbf{2 0 1 2}$ & $\mathbf{2 0 1 3}$ & $\mathbf{2 0 1 4}$ & $\mathbf{2 0 1 5}$ & $\mathbf{2 0 1 6}$ & $\left.\mathbf{2 0 1 7}^{*}\right)$ \\
\hline Parliamentary & 516.7 & 20.3 & 80.8 & 489.8 & 55.0 & 3.4 & 42.1 & 516.5 \\
Regional self- & 514.5 & 34.7 & 494.1 & 8.0 & 491.3 & 42.4 & 476.2 & 26.5 \\
government units & & & & & & & & \\
European Parliament & 25.0 & 0.0 & 0.0 & 0.0 & 450.0 & 3.7 & 0.0 & 0.0 \\
Presidential & 0.0 & 0.0 & 0.0 & 452.8 & 20.0 & 0.0 & 0.0 & 155.9 \\
Total & $\mathbf{1 , 0 5 6}$ & $\mathbf{5 5}$ & $\mathbf{5 7 5}$ & $\mathbf{9 5 1}$ & $\mathbf{1 , 0 1 6}$ & $\mathbf{5 0}$ & $\mathbf{5 1 8}$ & $\mathbf{6 9 8 . 9}$ \\
\hline
\end{tabular}

$\left.{ }^{*}\right)$ Approved budget.

According to election participation, the elections to the Chamber of Deputies are generally considered to be the most important elections in the Czech Republic, the voter turnout is around 60\% (see Figure 1). That is approximately three times higher than the Senate elections turnout. Generally, elections to the Senate and the European Parliament have the lowest turnout, which often does not reach $20 \%$. [4]

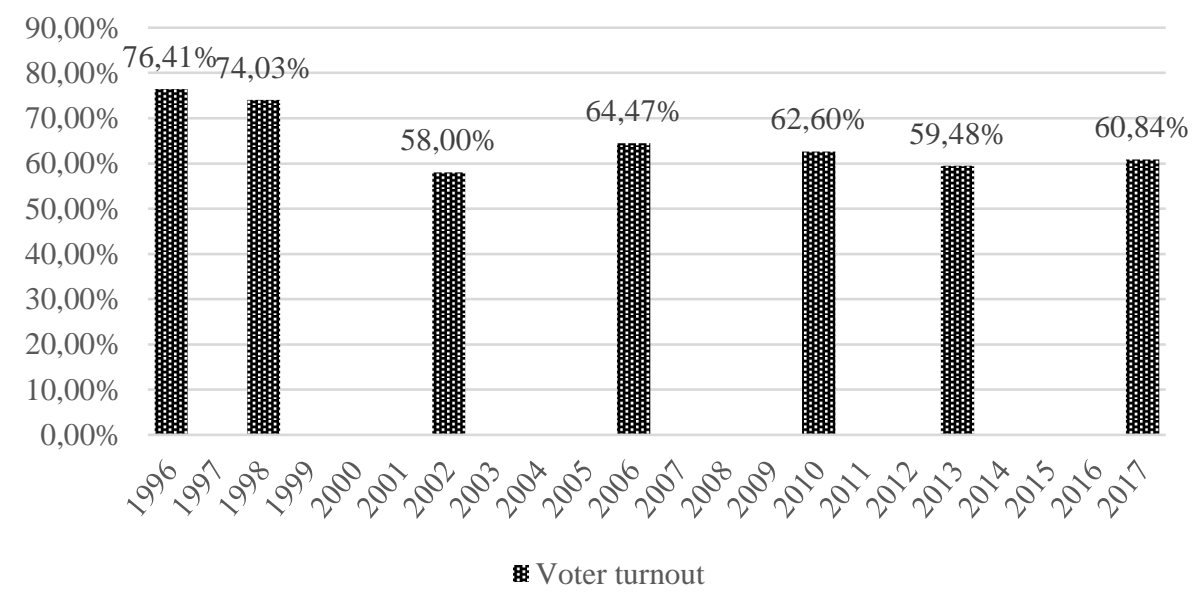

Fig. 1. Parliamentary elections voter turnout [4].

This paper focused on the analysis of the funds spent in connection with the preparation and execution of elections in the Czech Republic. Election data were selected for the elections to the Chamber of Deputies of the Parliament of the Czech Republic, which are considered the most important in the Czech Republic. Given that accurate and relevant data are available at the earliest one year after the elections, the paper used data about elections that took place in 2013 (financial data from the date of the same elections executed in autumn 2017, are not yet available in detailed bargaining). The aim of the paper is to analyze the most important cost items and to determine the basic characteristics, which would allow the evaluation of the individual municipalities' efficiency. 


\section{$3 \quad$ Results}

The total costs of execution the Parliamentary elections amounted to almost CZK 420 million. The most significant part of these costs (CZK 318.47 million, i.e. approx. 75\%) represented the costs of territorial self-governing units (municipalities and regions). The costs of the Czech Statistical Office, which processes the voting results, and the Ministry of the Interior, which participates in the organization and ensures the security of the voting process, was around CZK 50 million. Expenditures of other institutions (Ministry of Foreign Affairs and Ministry of Defence) are negligible:

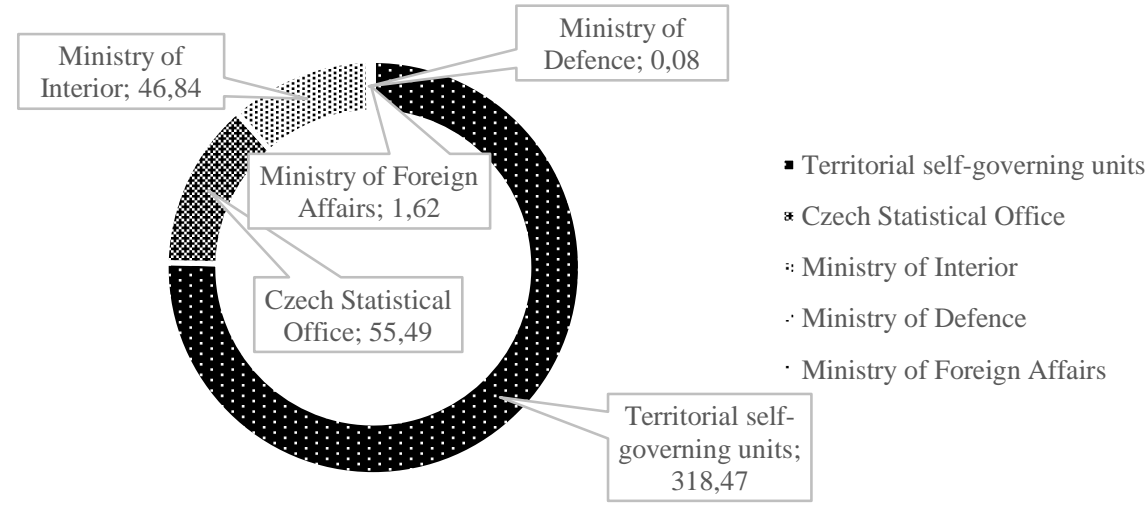

Fig. 2. Parliamentary elections (2013) costs [11].

Due to the very high share of costs of individual municipalities, the paper is focused on the analysis of these costs.

It is the duty of all municipalities to provide the polling stations in different ways either by using their own resources (e. g, municipal offices) or by renting other premises (e. g. public buildings, schools, kindergartens, but also restaurant facilities, etc.). The electoral room must be equipped for each electoral district, among other things, by a ballot box, a portable electoral box, a sufficient number of ballot papers, blank envelopes bearing the official stamp and writing supplies.

For the modification of the ballot papers, special spaces are designated in the polling stations to separate the ballot. The number of these spaces is determined by the mayor of the municipality, taking into account the number of voters in the electoral district. For each district, the mayor of the municipality appoints a district electoral commission whose number is determined by the number of eligible voters. The minimum number of members of the commission is determined by the number of eligible voters. If there are less than 300 eligible voters registered in the electoral district, only four members may have the commission, otherwise, it is necessary to appoint a commission of at least five members. The maximum number of members of the commissions is not limited. 
Furthermore, each polling station must have a telecommunication connection available, except that it can be equipped with computer equipment.

In general, it can be identified budget items that are most costly in terms of costs. These are mainly:

- Salaries of employees, respectively Other salaries (basic staff remuneration for training activities, methodological support, etc.);

- Other personnel costs (remuneration of members of the election commissions, remuneration for the distribution of ballot papers, cleaning of the polling station, all on the basis of working or working agreements with the relevant external staff);

- Purchase of other services (costs of service and rental of computer equipment, transportation, cleaning costs of the polling room provided externally, etc.);

- Purchase of material not elsewhere classified (costs for office supplies, paper, printer cartridges, etc.);

- Rent (the cost of renting the premises of the polling stations, authorized offices of the Czech Statistical Office (hereinafter referred to as the "reception area"), training rooms, etc.);

- Travel (in particular, the cost of transporting the voting results from the electoral district to the relevant take-over seat);

- Hospitality (staff and external employees' demands on meals).

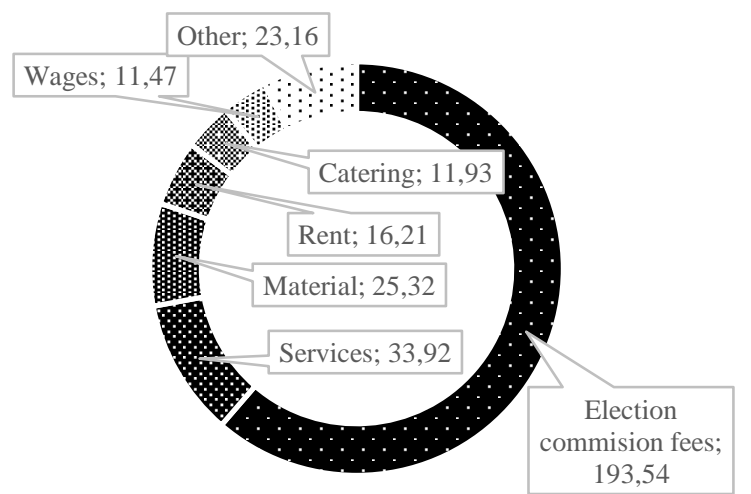

- Election commision fees

- Services

* Material

Rent

* Catering

:- Wages

Other

Fig. 3. Territorial self-governing units' costs (2013) - the most costly items [11].

All of the cost items above and other cost items appear as so-called variable variables, that is, their amount can be influenced by the relevant election authority (e. g. smaller number of members in district election commissions, more efficient purchases of office equipment or other services, securing polling stations and entertainment, etc.).

For the purposes of comparing the economy of individual municipalities, the indicators were used:

- The average total cost per electoral district,

- The average total cost per eligible voter. 
Table 2. Main characteristics of electoral districts.

\begin{tabular}{|c|c|c|c|c|c|}
\hline $\begin{array}{l}\text { Number of } \\
\text { eligible voters } \\
\text { in el. districts }\end{array}$ & $\begin{array}{l}\text { Total } \\
\text { number of } \\
\text { eligible } \\
\text { voters }\end{array}$ & $\begin{array}{l}\text { Total } \\
\text { number of } \\
\text { el. } \\
\text { districts }\end{array}$ & $\begin{array}{l}\text { Average } \\
\text { number of } \\
\text { eligible voters } \\
\text { per el. district }\end{array}$ & $\begin{array}{l}\text { Average } \\
\text { costs per el. } \\
\text { district }\end{array}$ & $\begin{array}{l}\text { Average costs } \\
\text { per eligible } \\
\text { voter }\end{array}$ \\
\hline $0-100$ & 55,973 & 771 & 71.38 & $12,660.51$ & 192.20 \\
\hline $101-200$ & 286,694 & 1,912 & 149.35 & $13,683.50$ & 95.03 \\
\hline $201-300$ & 339,423 & 1,375 & 246.08 & $14,897.50$ & 61.20 \\
\hline $301-400$ & 384,772 & 1,108 & 347.60 & $15,951.92$ & 46.21 \\
\hline $401-500$ & 417,001 & 925 & 447.30 & $16,747.31$ & 37.59 \\
\hline $501-600$ & 563,121 & 1,013 & 548.95 & $17,523.97$ & 31.94 \\
\hline $601-700$ & 797,141 & 1,210 & 651.28 & $19,067.64$ & 29.30 \\
\hline $701-800$ & $1,681,401$ & 2,236 & 749.70 & $19,829.95$ & 26.47 \\
\hline 801 - 900 & $2,304,046$ & 2,713 & 849.61 & $21,428.83$ & 25.25 \\
\hline $901-1000$ & 731,724 & 776 & 947.14 & $21,313.24$ & 22.53 \\
\hline $1001-1100$ & 314,211 & 302 & $1,046.39$ & $21,627.34$ & 20.69 \\
\hline $1101-1200$ & 211,552 & 184 & $1,150.13$ & $22,591.90$ & 19.66 \\
\hline $1201-1300$ & 109,771 & 88 & $1,248.88$ & $22,637.00$ & 18.13 \\
\hline $1301-1400$ & 57,893 & 43 & $1,347.31$ & $23,797.78$ & 17.64 \\
\hline $1401-1500$ & 49,129 & 34 & $1,444.45$ & $24,591.47$ & 17.02 \\
\hline $1500+$ & 102,744 & 61 & $1,691.29$ & $26,263.07$ & 15.67 \\
\hline Total & $8,406,596$ & 14,751 & 569.90 & $21,589.86$ & 37.88 \\
\hline
\end{tabular}

It is clear from the analysis that the highest costs for one voter are in smaller municipalities, respectively in small electoral districts and with an increasing number of voters in the electoral district these costs are declining. However, the municipalities may affect the number of eligible voters in the districts only partially. In the Czech Republic, there is a high number of municipalities where the low number of inhabitants (and therefore the eligible voters) lives, but the electoral district (polling stations) has to be established. These small municipalities have higher costs per eligible voter, while municipalities with more electoral districts will realize "economies of scale" (Fig. 4): 


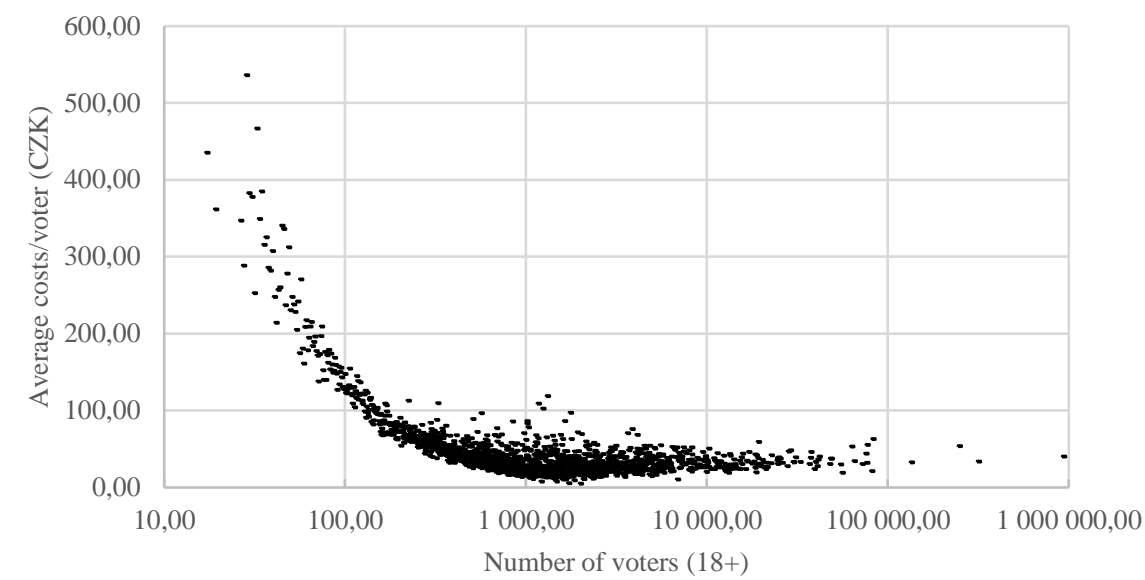

Fig. 4. Average costs per eligible voter (according to the number of eligible voters in municipalities).

A rather unexpected fact is the rising trend of costs per electoral district depending on the number of eligible voters in the municipality (Fig. 5). Larger municipalities have higher costs per electoral district (polling station, a unit of polling). This trend can be described by a logarithmic regression function $y=2571.6 \ln (x)+931.14$.

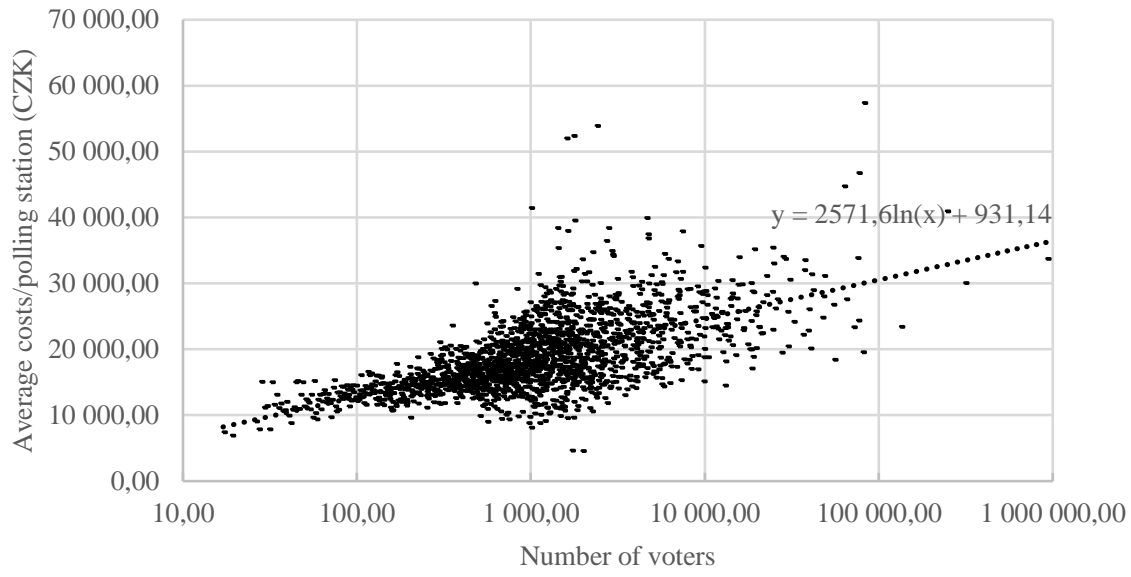

Fig. 5. Average costs per electoral district (according to the number of eligible voters in municipalities).

There is also a statistically significant difference in the amounts which municipalities with the same scope of competence [10] (divided into the Capital City of Prague, statutory cities, municipalities with extended powers (III.ST), authorized municipal 
authorities (II.ST) and municipalities with basic scope of state administration (I.ST) spend on one electoral district:

Table 3. Main characteristics of municipalities classified according to the scope of competence.

\begin{tabular}{lrrrr}
\hline $\begin{array}{l}\text { Municipality } \\
\text { competence }\end{array}$ & $\begin{array}{l}\text { Number of } \\
\text { municipalities }\end{array}$ & $\begin{array}{l}\text { Number of el. } \\
\text { districts }\end{array}$ & \multicolumn{1}{l}{ Total costs } & \multicolumn{2}{c}{$\begin{array}{l}\text { Average costs per } \\
\text { el. district }\end{array}$} \\
\hline Prague (capital) & 1 & 1101 & $37,077,520$ & $33,676.22$ \\
Statutory cities & 25 & 2,294 & $71,548,342$ & $31,189.34$ \\
III.ST & 180 & 2,669 & $65,590,527$ & $24,574.94$ \\
II.ST & 183 & 944 & $20,718,348$ & $21,947.40$ \\
I.ST & 5,845 & 7,743 & $122,449,260$ & $15,814.19$ \\
Total & $\mathbf{6 , 2 3 4}$ & $\mathbf{1 4 , 7 5 1}$ & $\mathbf{3 1 8 , 4 7 1 , 9 6 3}$ & $\mathbf{2 1 , 5 8 9 . 8 6}$ \\
\hline
\end{tabular}

For example, there were spent CZK 19,511.28 per one electoral district in Liberec, CZK 24,310.14 in Hradec Kralove and CZK 33,832.04 in Ústí nad Labem. The capital - Prague, which has more than 1,100 electoral districts, has a cost per electoral district of 33,676.22 CZK. The average national costs per one electoral district were only CZK 21,589.86.

\section{Discussion and Conclusion}

Contributions that work with electoral systems in terms of their cost-effectiveness are very rare. The reason can be the sensitivity of this topic from the point of view that "democracy is worth something" or "democracy is not free of charge". Many researchers, however, pay attention to sociological aspects - they examine decisionmaking and voter preferences, or influences that have an impact on voter turnout. [3, $5,6]$ The aim of this paper was to create and broaden the view of the perceptions of the election not only as a social problem of the choice theory [12] but also of the cost of the society itself. Motives for people should be, therefore, using their legal rights $[13,14,15,16,17,18]$ and to participation not only in order to determine the future direction of the territorial unit in which they live but also to use the public services offered to them by the country. Only then these services can be evaluated as effective and meaningful.

This paper analysed the costs of execution elections in the Chamber of Deputies of the Parliament of the Czech Republic. It was found that approximately $75 \%$ of the total costs of the elections (CZK 318 million) represent the costs of territorial selfgoverning units. Of this amount, the highest share (61\%, i.e. about 194 million CZK) represents wages by the electoral district election commissions. The analysis of the distribution of costs according to the size of the municipalities showed that with the increasing size of the municipality, its average cost for one electoral district increases, and therefore does not realize any "economies of scale". In addition to this fact, the 
costs of similar municipalities (according to their competence) differ significantly, for example in the statuary cities by up to $73 \%$.

The space to reduce these costs is in the number of electoral districts so (and therefore in electoral commissions or a number of its members) with maintaining the same availability of the polling station for citizens. This is partially possible for larger cities that establish polling stations in school premises, with more than one polling station in one such building. This would save a significant amount and make the election process more cost-effective and more efficient.

Acknowledgement. This study is supported by internal research project No. 2103 Investment evaluation within concept Industry 4.0 at Faculty of Informatics and Management, University of Hradec Kralove, Czech Republic.

\section{References}

1. Blais, A., Gidengil, E., Nevitte, N.: Where does turnout decline come from? European Journal of Political Research 43(2), 221-236 (2004). DOI: 10.1111/j.14756765.2004.00152.x.

2. Blais, A.: To vote or not to vote?: the merits and limits of rational choice theory. 1st edn. University of Pittsburgh Press, Pittsburgh (2000).

3. Bowler, S., Brunell, T., Donovan, T., Gronke, P.: Election administration and perceptions of fair elections. Electoral Studies 38(June 2015), 1-9 (2015), DOI: 10.1016/j.electstud.2015.01.004.

4. Czech Statistical Office: Volby.cz, http://volby.cz/, last accessed 2017/12/03.

5. Garmann, S.: Election frequency, choice fatigue, and voter turnout. European Journal of Political Economy 47(March 2017) 19-35, (2017), DOI: 10.1016/j.ejpoleco.2016.12.003.

6. Kerr, N., Lührmann, A.: Public trust in manipulated elections: The role of election administration and media freedom. Electoral Studies 50(December 2017), 50-67 (2017), DOI: 10.1016/j.electstud.2017.08.003.

7. Klíma, M.: Srovnání stranických a volebních systémů ve vyspělých demokratických zemích. 1st edn. Radix, Prague (2003).

8. Kostelecký, T., Mikešová, R., Poláková, M., Čermák, D., Bernard, J., Šimon, M.: Geografie výsledků parlamentních voleb: vzorce volebního chování v Česku 1992-2013. 1st edn. Sociologický ústav AV ČR, v.v.i., Prague (2015).

9. LeDuc, L., Niemi, R. G., Norris, P.: Comparing Democracies 2: New challenges in the study of elections and voting. 1st edn. Sage, London (2002).

10. Ministry for Regional Development: Portál územního plánování, http://portal.uur.cz/spravni-usporadani-cr-organy-uzemniho-planovani/obce.asp, last accessed 2017/12/04.

11. Monitor: Analytical part of portal Monitor, http://monitor.statnipokladna.cz/analyza/, last accessed 2017/12/07.

12. Nagler, M. G.: Trading off the benefits and costs of choice: Evidence from Australian elections. Journal of Economic Behavior \& Organization 114(June 2015), 1-12 (2015), DOI: 10.1016/j.jebo.2015.03.004.

13. Parliament of the Czech Republic: Ústava České republiky. L 1/1993. 
14. Parliament of the Czech Republic: Zákon o volbě prezidenta republiky a o změně některých zákonů. L 275/2012.

15. Parliament of the Czech Republic: Zákon o volbách do Evropského parlamentu a o změně některých zákonů. L 62/2003.

16. Parliament of the Czech Republic: Zákon o volbách do Parlamentu České republiky a o změně a doplnění některých dalších zákonů. L 247/1995.

17. Parliament of the Czech Republic: Zákon o volbách do zastupitelstev krajů a o změně některých zákonů. L 130/2000.

18. Parliament of the Czech Republic: Zákon o volbách do zastupitelstev obcí a o změně některých zákonů. L 491/2001.

19. Reterová, S.: Alternativní způsoby hlasování. Od tradičních metod k on-line volbám. 1st edn. Periplum, Prague (2008).

20. Sandroni, A., Feddersen, T. J.: A theory of ethics and participation in elections. 1st edn. School of Economics \& Finance, University of Hong Kong, Hong Kong (2001).

21. Supreme Audit Office of the Czech Republic: Funds spent in relation to preparation and execution of elections, https://nku.cz/assets/kon-zavery/K15036_EN.pdf, last accessed 2017/11/23. 